\title{
Assessment and Retrofit of the Bridge over Kouris River, Cyprus
}

\author{
Chrysanthos Maraveas ${ }^{1,2}$, Konstantina Tasiouli ${ }^{2}$ \\ ${ }^{1}$ ArGEnCo Department, University of Liege, Liege, Belgium \\ ${ }^{2}$ Maraveas \& Associates, P.C., Athens, Greece \\ Email: c.maraveas@maraveas.gr
}

How to cite this paper: Maraveas, C. and Tasiouli, K. (2017) Assessment and Retrofit of the Bridge over Kouris River, Cyprus. Open Journal of Civil Engineering, 7, 336-347. https://doi.org/10.4236/ojce.2017.73023

Received: June 22, 2017

Accepted: July 18, 2017

Published: July 21, 2017

Copyright (C) 2017 by authors and Scientific Research Publishing Inc. This work is licensed under the Creative Commons Attribution International License (CC BY 4.0).

http://creativecommons.org/licenses/by/4.0/

\section{(c) (†) Open Access}

\begin{abstract}
The main objective of the present study is the assessment and retrofit of an existing road bridge that is located in Cyprus over the river Kouris. In particular the study concerns in a road bridge with seven spans of $10.5 \mathrm{~m}+5 * 12.6$ $\mathrm{m}+10.5 \mathrm{~m}$, a cross section width of $7.10 \mathrm{~m}$ and a $5 \mathrm{~m}$ piers height that was constructed in the early 50's. The structural system of the bridge comprises of cast in situ reinforced concrete T-beams and slab deck that is simply supported on masonry piers. According to the new urban plan to design the bridge should now accommodate two lanes per direction, a pedestrian walkway and a cycling lane with total cross section width of new deck $15.60 \mathrm{~m}$. The deck of the bridge widened using for aesthetic reasons the same cross section type and the new T-Beams and slab deck connected monolithically to the existing one. The existing part of the deck was strengthened with reinforced concrete jacketing due to inadequacy in shear resistance. Major challenge of the project posed the existing masonry pier layout that was insufficient to carry the new design seismic forces. New piers, founded on piles, were designed adjacent to the existing piers in order to support the new widened part of the bridge, and also to bear all the horizontal loads arising from the masses of the total deck. Sliding bearings (free movement) placed in the part of the bridge over the existing piers and elastomeric bearings with movement only in the longitudinal direction placed in the new piers.
\end{abstract}

\section{Keywords}

Bridge, Retrofit, Bearings, Concrete Jacketing, FRP

\section{Introduction}

The bridge over river Kouris that will be discussed in this paper is part of the old 
national road Limassol-Paphos near ancient Kourion at Episkopi Cyprus. The existing bridge was constructed in the early 50 's and is $83.60 \mathrm{~m}$ long with seven spans (Figure 1). Its carriageway consists of one lane per direction and lies on a straight line in plan and elevation. The total width of the deck (including the sidewalks) is $6.45 \mathrm{~m}$.

According to the new master plan of Episkopi Municipality the old national road has to be widened and upgraded in order to carry heavier traffic loads. Thus a new cross section of the road was decided which accommodates two lanes per direction a pedestrian walkway and a cycling lane with total cross section width of the new deck $15.60 \mathrm{~m}$. Also the new bridge has to satisfy the much newer strictest seismic code (Eurocode 8) which is applicable in Cyprus.

Following the above restrictions a detailed study was carried out in order to find the most economical and advanced solution for the river crossing. At the following pages we will present the proposed retrofit design that was selected as the most economical for the existing bridge, the advanced seismic solutions that were given so as to account for the high seismicity of the region and the new traffic loads as mentioned above. Also we should mention that although the river has medium to high flow with a river bed of approximately $85 \mathrm{~m}$ thanks to the advanced structural solution no pier retrofit was required and so no riverbed rearrangement was needed leading to higher saving to the Municipally.

\section{Structural Layout of Existing Bridge}

The existing bridge is $83.60 \mathrm{~m}$ long with seven spans of length $2 * 10.45 \mathrm{~m}+2$ * $12.60 \mathrm{~m}+3 * 12.50 \mathrm{~m}$ Figure $2(\mathrm{a})$ and Figure $2(\mathrm{~b})$. The deck of the bridge comprises of reinforced concrete girders with deck slab. The girders have $1.85 \mathrm{~m}$ spacing along deck cross section and at the location of the piers they are connected with crossing beam with $40 \mathrm{~cm}$ thickness. The thickness of the deck slab is $18 \mathrm{~cm}$ and the beams have web thickness $50 \mathrm{~cm}$ and height $93 \mathrm{~cm}$ at the middle spans and $68 \mathrm{~cm}$ at the end spans Figure 3.
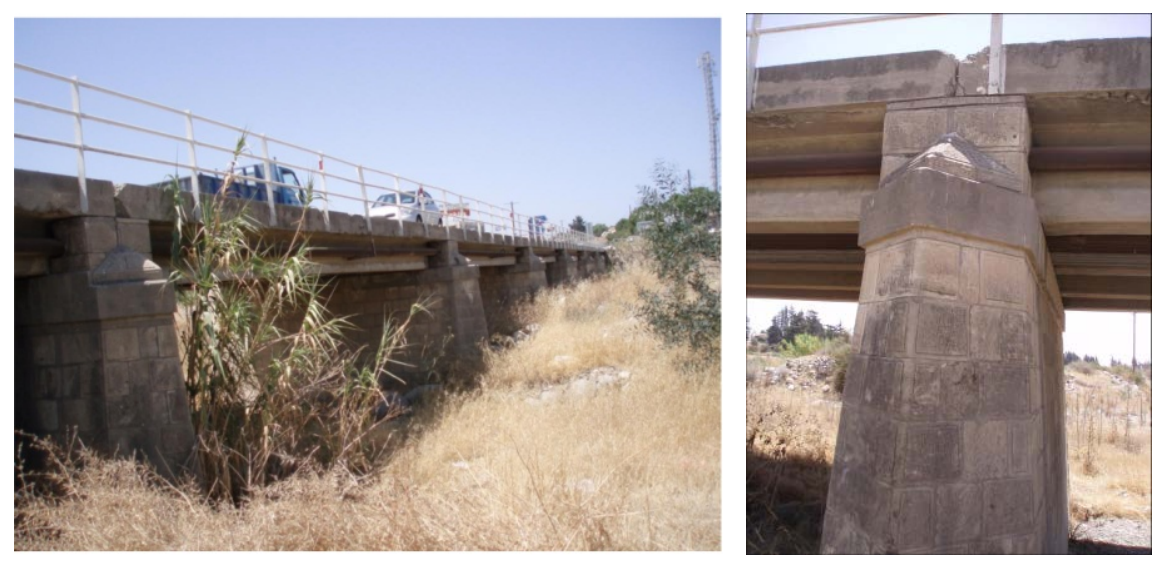

Figure 1. Typical photos of the existing bridge (Longitudinal view of the bridge and the pier). 


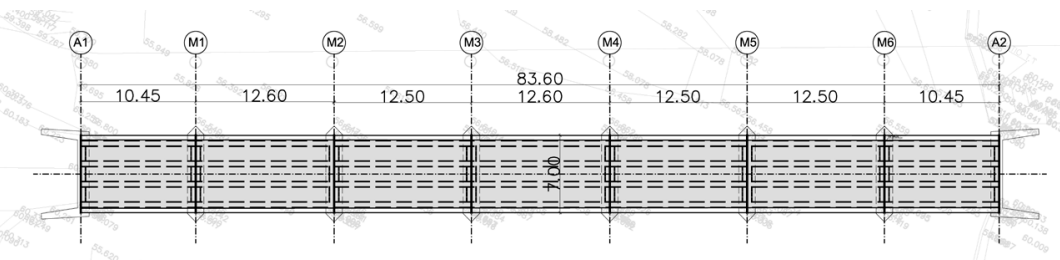

(a)

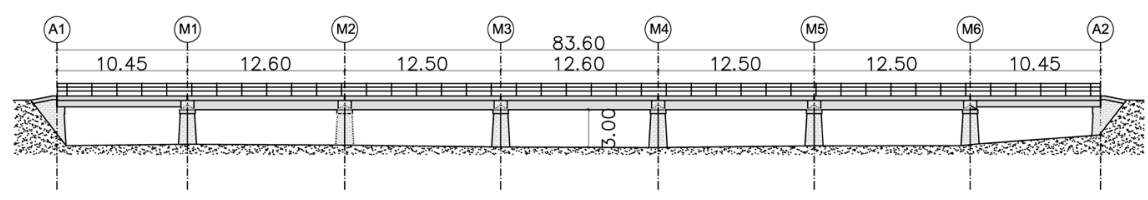

(b)

Figure 2. General arrangement of the bridge. (a) Plan view of the bridge; (b) Elevation of the bridge.

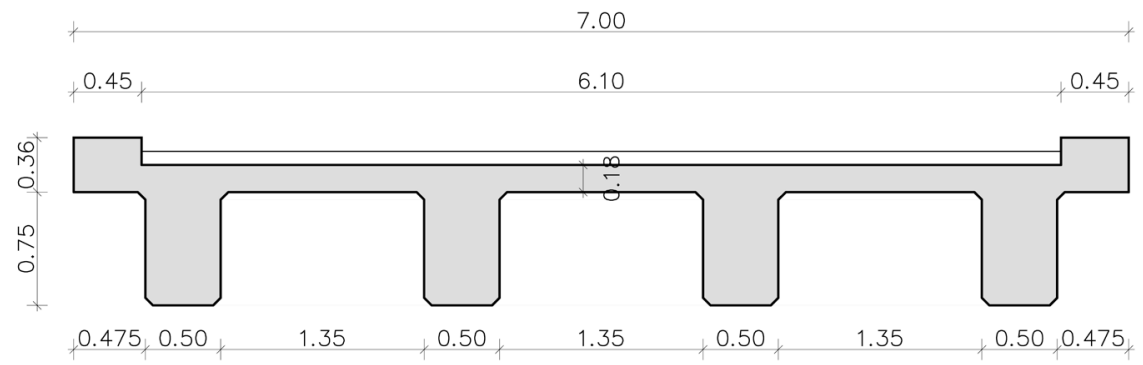

(a)
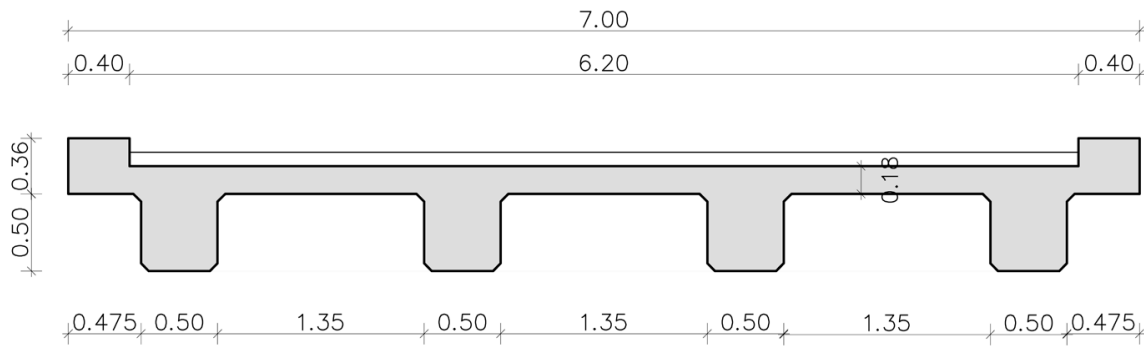

(b)

Figure 3. Deck cross sections (Typical deck cross section of middle spans (top) and end).

The deck is simply supported on piers with approximately $3 \mathrm{~m}$ height. The piers cross section comprises of unreinforced concrete core with constant thickness of $0.30 \mathrm{~m}$ and outer layer of masonry with variable thickness of $0.20 \mathrm{~m}$ on the top and $0.38 \mathrm{~m}$ on the bottom Figure $1(\mathrm{~b})$. The total width of piers cross section is variable along their height $8.00 \mathrm{~m}-8.70 \mathrm{~m}$ Figure 4 . The piers are founded on raft foundation with $11.45 \mathrm{~m}$ width and $1.00 \mathrm{~m}$ thickness. The abutments of the bridge are made of unreinforced concrete with an outer layer of masonry.

At the preliminary stage of the design an extended in-situ survey was made in order to establish structural details and estimate loads. Laboratory tests were also conducted on samples taken from the field to evaluate the mechanical properties 


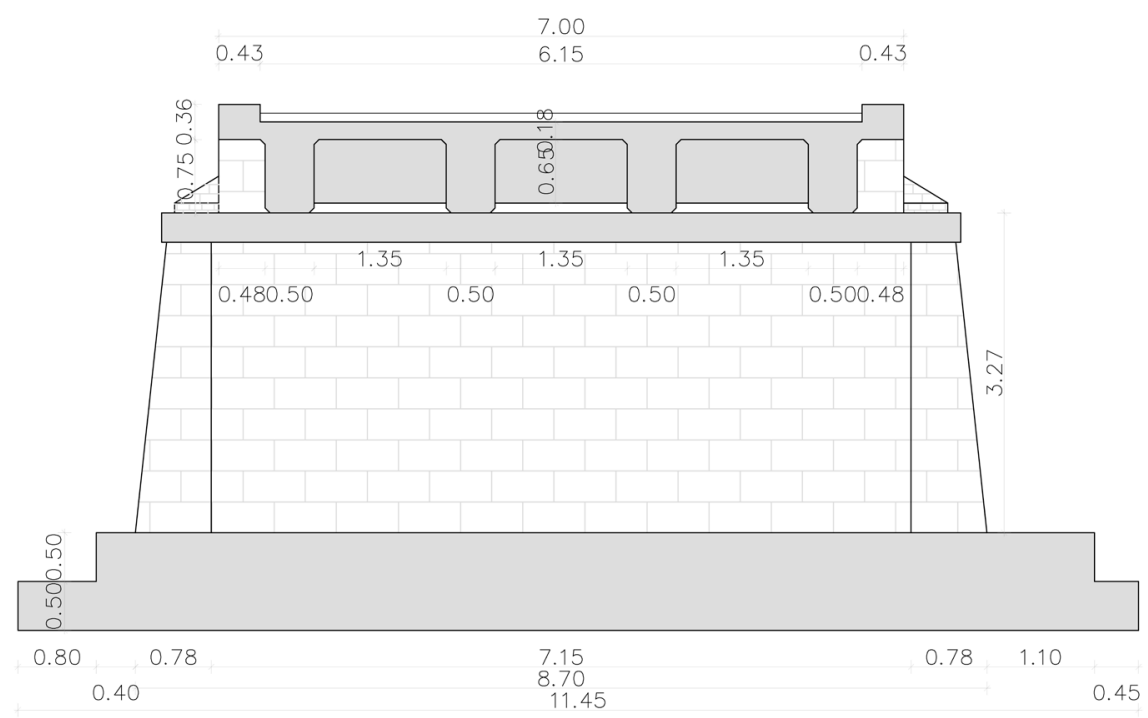

Figure 4. Pier geometry (Typical section at the pier).

of materials. Specifically, tests were made for the compressive strength of stone masonry and concrete and chemical analyses on mortars. Also test to evaluate the rate of corrosion of the existing reinforcement and the carbonation rate of concrete were performed.

\section{Performance and Design Principles}

The main objective of this study is the evaluation of the structural adequacy of the bridge and the retrofit of the modified bridge with a wider deck of $14.60 \mathrm{~m}$ instead of $7.00 \mathrm{~m}$ according to the new Master Plan and the new increased traffic and seismic loads. The bridge was constructed in early 50's. At those years the structural design principles was neglecting durability requirements and also increased seismic forces.

At the first stage of the in-situ survey corrosion of reinforcement, and cracks at the pavement in the joints between adjacent spans was mainly established. In order to evaluate material mechanical properties concrete and masonry core samples was taken and rebound hammer test performed for the deck and the piers according to CYS EN 12504-1 [1]. For the reinforcement steel samples were taken and tensile tests were conducted according to EN ISO 6892-1 [2] (Table 1).

As per Employers Requirements the assessment of the existing bridge was performed for the design loads imposed by EN 1991-1-1 [3], EN 1991-2 [4], EN 1998 [5], for bridges following National Annexes of Cyprus. Especially: (Table 2).

\section{Structural Evaluation of Existing Bridge}

For the assessment of the existing bridge an exhaustive series of analyses were performed. The bridge was simulated as a $3 \mathrm{D}$ spatial frame with grillage for the 
Table 1. Mechanical properties of material of existing bridge.

\begin{tabular}{cc}
\hline Concrete Beams and Deck Slab & C20/25 \\
Concrete of Piers & $\mathrm{C} 16 / 20$ \\
Reinforcement Steel & $\mathrm{S} 220$ \\
Compressive strength of Stone Masonry of Piers & $18 \mathrm{MPa}$ \\
Shear strength of Stone Masonry of Piers & $3.5 \mathrm{MPa}$ \\
\hline
\end{tabular}

Table 2. Design loads of redesigned bridge.

Temperature Loads
Wind Loads
Traffic Loads

Seismic Loads

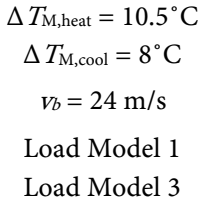

Elastic Response Spectrum Type 1:

$$
\begin{aligned}
a_{g R} & =0.25 \mathrm{~g} \\
\gamma_{I} & =1.30 \\
\eta & =1.00 \\
S & =1.20 \\
T_{B} & =0.15 \mathrm{sec} \\
T_{B} & =0.50 \mathrm{sec} \\
T_{D} & =2.00 \mathrm{sec}
\end{aligned}
$$

deck, using the commercial program RM Bridge 2000 (Bentley) [6] which performs $4 \mathrm{D}$ time-dependent analysis throughout the construction progress Figures 5. The bridge was assumed to be fixed at its supports. The connection of deck to existing priers was assumed to be pinned. The design followed the regulations of the EN 1992 [7] and EN1998 [5] in conjunction with BD 44/95 [8] and the necessary checks were performed. More specifically, serviceability was checked by limiting the compressive and tensile stresses in concrete and steel, in conjunction with performing checks for the control of cracking. Regarding the ultimate limit state, the bending and shear resistance of the girder were calculated Equations (1) and (2) and the longitudinal reinforcement provided. For the unreinforced-masonry piers checks were performed according BD21/01 [9], BD44/95 [8] and EN 1996-1-1 [10] for the equivalent masonry cross section. The most critical design resistances are presented hereafter for concrete beams and unreinforced masonry piers.

$$
M_{u}=\frac{f_{y}}{\gamma_{m s}} \cdot A_{s} \cdot\left(d-\frac{h_{f}}{2}\right), M_{u}=0.60 \cdot \frac{f_{c u}}{\gamma_{m c}} \cdot b_{e f f} \cdot h_{f} \cdot\left(d-\frac{h_{f}}{2}\right)
$$

BD44/95 Vol. 3 Section 4. par. 5.3.2 Equations (6) and (7) (1), (2)

$$
v_{c . \max }=\left\{\begin{array}{c}
0.92 \cdot \sqrt{\frac{f_{c u}}{\gamma_{m c}}} \\
\frac{7}{\sqrt{\gamma_{m c}}}
\end{array}\right\}, V_{u}=\xi_{s} \cdot v_{c} \cdot b_{w} \cdot d+\frac{f_{y v}}{\gamma_{m s}} \cdot \frac{d}{s_{v}} \cdot A_{s v}
$$

BD44/95 Vol. 3 Section 4. par. 5.3.3 


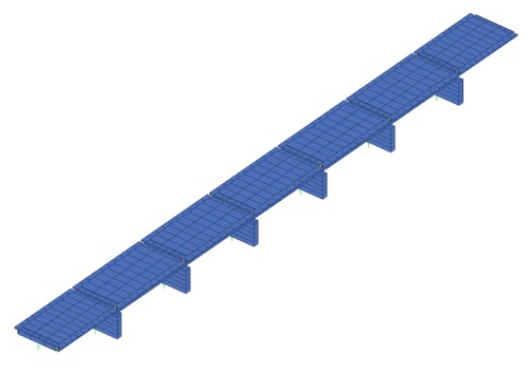

(a)

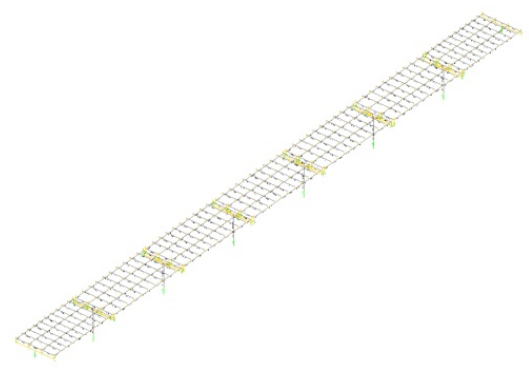

(b)

Figure 5. Extracts from the analysis model of existing bridge. (a) Model of analysis rendered; (b) Model of analysis beam elements.

$$
\begin{aligned}
& f_{k}=K \cdot f_{b}^{0.7} \cdot f_{m}^{0.3} \quad \text { EN 1996-1 par. 3.6.1.2 } \\
& f_{v}=f_{v k o}+0.6 \cdot \sigma_{d} \quad \text { EN 1996-1 par. 3.6.2 }
\end{aligned}
$$

Sensitivity analyses were also conducted for all the parameters that were assumed to be not clearly defined and more specifically for the mechanical characteristics of the mortar of masonry piers. According to EN 1996-1-1 [10], the design resistance of masonry piers depends on the type of mortar. Two extreme cases of M12 and M2 mortar categories were assumed according to EN 1996-1-1 [10]. The influence of mortar characteristics on bending and shear resistance of masonry piers is presented in the following Table 3 in terms of safety factor. More specifically:

Safety factor-Bending Moment: Design Force (Msd)/Resistance (MRd)

Safety factor-Shear Resistance: Design Force (Vsd)/Resistance (VRd)

According to the results of all the assessment analyses the bending and shear resistance of the bridge deck was exceeded for the loads imposed by traffic Load Model 3. The bending resistance of unreinforced-masonry piers was also exceeded for the imposed seismic loads but the piers could adequately deliver all vertical forces imposed by new loads. The same applies also for the resistance of the connection with the deck. Finally the foundation of bridge could also adequately resist all the new increased design forces

\section{Structural Design-Rehabilitation Alternatives of the New Redesigned Bridge}

According to the new Master plan of Episkopi the new deck of the bridge should have width $14.60 \mathrm{~m}$ instead of $7.00 \mathrm{~m}$ that was the existing bridge. The new traffic lanes width is $9.50 \mathrm{~m}$ and $5.50 \mathrm{~m}$ of which lie on the existing part of the bridge.

The new bridge should resist all loads provided by Eurocodes and especially traffic load 1200/200 of Load model 3 as per EN1991-2 [4]. The existing part of the bridge is inadequate to resist this load in terms of bending moment and shear force. 
Table 3. Safety factor of Bending and Shear resistance of Masonry piers.

\begin{tabular}{lccc}
\hline & & Bending Moment & Shear \\
\hline \multirow{2}{*}{ Mortar M2 } & ULS & 1.95 & 1.65 \\
& EARTHQUAKE & 0.34 & 0.31 \\
\multirow{2}{*}{ Mortar M12 } & ULS & 3.51 & 3.30 \\
& EARTHQUAKE & 0.58 & 0.65 \\
\hline
\end{tabular}

The major challenges of the redesigned bridge were to widen the deck at almost twice of the existing and simultaneously to maintain the initial characteristics of the existing bridge while rehabilitating its inadequacies. The basic principles of the redesign are presented in flow chart of Figure 6.

The locations of the existing piers should be the same as the new because of the river, which flow should not be disturbed. Due to the small distance between the new foundation and the existing, bored piles were incorporated for the foundation of the new piers. The effects of the piles are negligible to the existing adjacent raft foundation. Taking into consideration the aforementioned, the new part of the deck was decided to have the same span layout and cross section with the existing.

The two parts of the deck were decided to be monolithically connected transversely because the existing bridge has already seven simply supported spans longitudinally. If a longitudinal joint was provided for the two parts of the deck many issues would have to be faced. The major was that the joint would be placed along the middle of traffic lanes and this poses safety and serviceability problems in the traffic. Also by providing a rubber expansion joint which has a design life smaller than the bridge deck would result in necessary repair works in the deck during service life of the bridge. Finally during earthquake the deck would not have a diagram response and the differential movements between deferent parts should be incorporated by the horizontal expansion joints for the total length of the bridge.

The existing part of the deck was connected to the piers by pinned connection which proved to be inadequate to resist new increased seismic forces as per assessment analyses. The redesigned deck was decided to be connected to the piers with elastomeric bearings due to the fact that a new super elevation according to the road design should be incorporated and also the widened deck is supported by different type of piers and foundation along its cross section. Moreover elastomeric bearings will be designed to resist the new increased seismic forces and also act as seismic isolation for the existing inadequate unreinforced-masonry piers.

A new deck cross section equivalent to the existing has to be designed for the new use of the bridge. The new part of the deck will be designed to resist all the new increased loads but the existing should be retrofitted. The bending moment and shear resistance of the existing bridge were exceeded (Table 4). Retrofit 


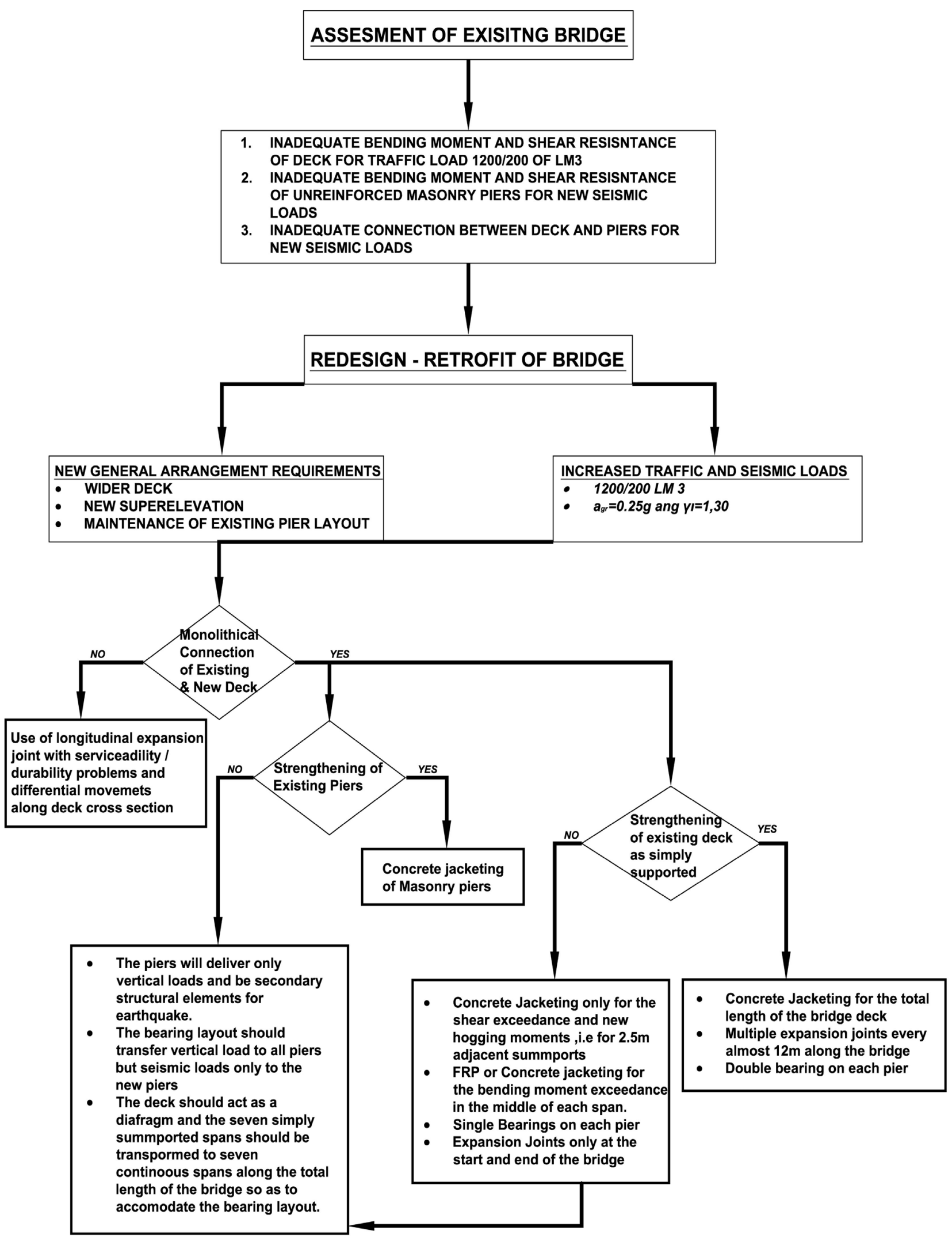

Figure 6. Basic principles of redesign of Episkopi Bridge. 
Table 4. Bridge structural member's assessment.

\begin{tabular}{ccccccc}
\hline & \multicolumn{3}{c}{ Bending Moment } & \multicolumn{3}{c}{ Shear Force } \\
\cline { 2 - 7 } Structural Member & $\begin{array}{c}\text { Design Force Resistance } \\
\left(\mathrm{M}_{\mathrm{sd}}\right)\end{array}$ & $\begin{array}{c}\text { Safety } \\
\left(\mathrm{M}_{\mathrm{Rd}}\right)\end{array}$ & $\begin{array}{c}\text { Design Force } \\
\left(\mathrm{V}_{\text {sd }}\right)\end{array}$ & $\begin{array}{c}\text { Resistance } \\
\left(\mathrm{V}_{\mathrm{Rd}}\right)\end{array}$ & $\begin{array}{c}\text { Safety } \\
\text { factor }\end{array}$ \\
\hline Beam End Spans & 1830 & 750 & 0.41 & 1050 & 285 & 0.27 \\
Beam Middle Spans & 2440 & 1365 & 0.56 & 1150 & 430 & 0.37 \\
Piers & 4000 & 1360 & 0.34 & 1300 & 406 & 0.31 \\
\hline
\end{tabular}

methods with concrete jacketing or with FRPs are common practices for those inadequacies in concrete structures. The use of FRP's is not recommended for members with high rates of inadequacy in the brittle failure of shear. The beams of the lack almost $700 \mathrm{kN}$ shear force which is over $60 \%$ higher than their initial resistance and this lead to the use of reinforced concrete jacketing for the retrofit of the girders.

As far as the existing piers are concerned, which inadequacy to horizontal seismic loads is already presented in Table 3 and Table 4, the implementation of concrete jacketing was studied at the preliminary stage. In order to apply it the outer masonry layer should be removed in order to connect the new and the existing concrete and transfer interface forces adequately. This lead not only to major interventions with increased cost but it was also opposing to the preservation of the initial characteristics of the masonry piers.

\section{Structural Design of the Final Proposal of the New Redesigned Bridge}

Taking into consideration all the preliminary assumptions the final decision was to compare techno-economically two solutions for the bridge.

The first was to maintain the simply supported spans and strengthen both existing deck and piers while placing elastomeric bearings and expansion joints in every span. The second, which was finally adopted, was to strengthen only the existing part of the deck without any interventions on the existing piers Figure 7. Prerequisite of the second solution is to design a seismic isolation system that would adequately transfer horizontal loads only to the new piers while vertical loads to both existing and new piers.

More specifically the bridge deck is redesigned as continuous in the longitudinal direction by monolithically connect the beams above the piers Figure 7 . Also in order to connect the existing and the new cross section transversally the existing deck slab and cross beams are demolished. Reinforced concrete jacketing is applied to the existing main beams and in-situ reinforced concrete is applied for the demolished deck slab and the new part of the deck. The thickness of the concrete jacketing is $10 \mathrm{~cm}-15 \mathrm{~cm}$.

As far as the bridge deck is formed as continuous in the longitudinal direction 


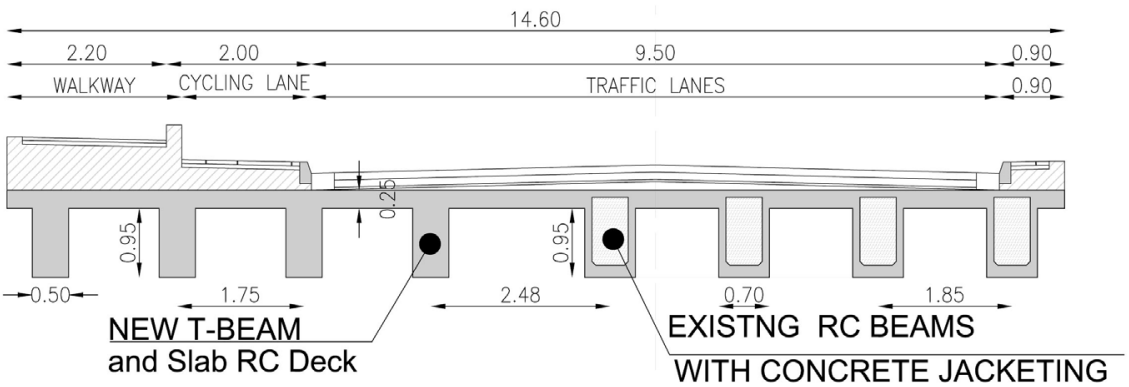

(a)

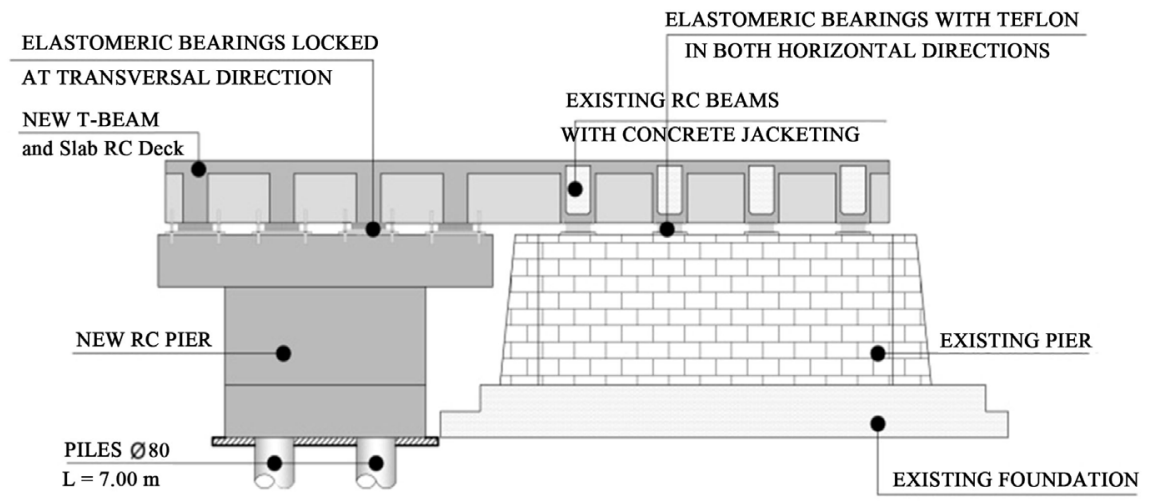

(b)

Figure 7. Sections of new redesigned bridge. (a) Typical deck cross section of middle spans; (b) Typical bridge cross section at piers.

with width of $14.60 \mathrm{~m}$, elastomeric bearings are designed to be placed above its pier in order to seismically isolate bridge deck from the existing piers. Elastomeric bearings type ALGA NBU 700/800/104 locked at transversal direction was placed above the new pier and PTFE bearings type ALGA NTM 300/500/59 with release in both horizontal directions was placed above the existing piers Figure 8.

The aforementioned bearings layout resulted in almost negligible horizontal forces to the existing piers and to deliver the shear force of both horizontal directions and torsion resulting from deck movements during earthquake to the new reinforced concrete piers. Due to small span length the resulting forces to the new piers can safely be transferred only to the new piers which are reinforced adequately to resist all the new forces.

By implementation of a continuous bridge deck expansion joints are used only at the start and the end of the bridge. This result not only to lower initial cost but to lower maintenance cost. Also the two expansion joints result to smaller disturbance of traffic.

\section{Cost Data-Material Quantities}

The bridge estimated cost is $850,000 €$. A summary of the quantities of the basic materials is shown in Table 5. 


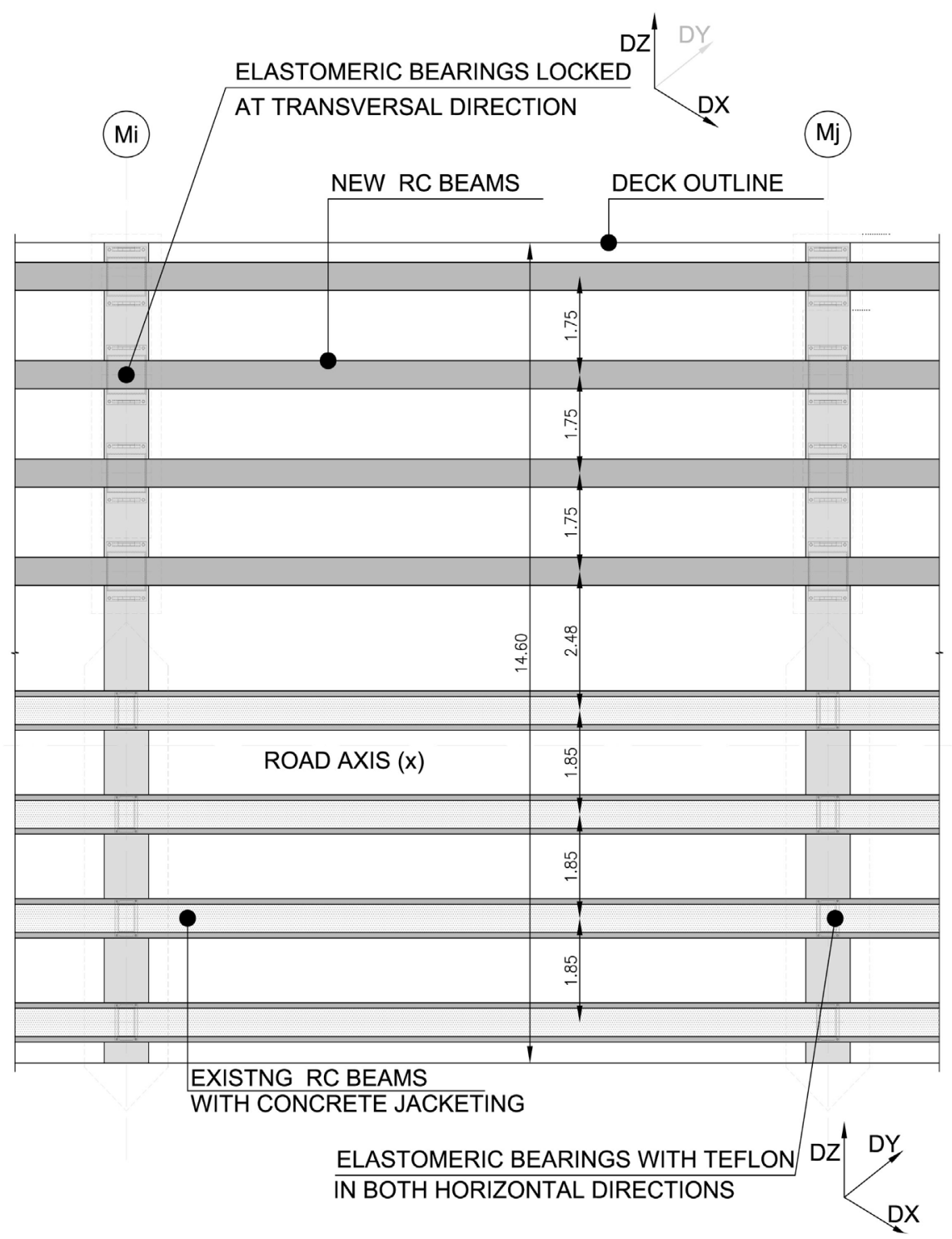

Figure 8. General layout of new redesigned bridge. Typical layout of middle span of new redesigned bridge.

Table 5. Basic material quantities of redesigned bridge.

\begin{tabular}{cc}
\hline Reinforced Concrete C35/45 & $1300 \mathrm{~m}^{3}$ \\
Reinforced Concrete jacketing C35/45 & $300 \mathrm{~m}^{3}$ \\
Bored piles & $170 \mathrm{~m}$ \\
Bearings type Alga NBU 700/800/104 & $32 \mathrm{nos}$ \\
Bearings type Alga NTM 300/500/59 & $32 \mathrm{nos}$ \\
\hline
\end{tabular}

\section{Conclusions}

The bridge over river Kouris is part of the old road Limassol-Paphos at Episkopi Cyprus. The existing bridge was constructed in the early ' 50 s, and has seven 
spans with total length $83.60 \mathrm{~m}$ and $6.45 \mathrm{~m}$ deck width. According to the new master plan of Episkopi Municipality the bridge has to be redesigned so as to accommodate one line per direction, sidewalks, and cycle lanes with a total width of new deck $14.60 \mathrm{~m}$ and new increased traffic and seismic loads. Assessment and retrofit design of the redesigned bridge consisted of extensive study of alternative solutions and ended up by incorporating an innovative solution of strengthening only the existing part of the deck without any interventions/ strengthening on the existing piers. The bridge deck was widened by equivalent cross section fully connected to the existing one by reinforced concrete jacketing and is redesigned as continuous in the longitudinal direction by monolithically connecting the beams above its pier. Special seismic isolation layout was selected so as to release the existing piers in earthquake and deliver seismic forces only to the new piers and foundation.

The solution that was given at Kouris River Bridge can be used in a lot more of existing bridges where there is the necessity to widen the carriageway the necessity to bear heavier traffic and seismic loads and at the same time there is a difficulty in strengthening the existing piers and foundations.

\section{References}

[1] British Standard (2009) BS EN 12504-1-Testing Concrete in Structures. Cored Specimens. Taking, Examining and Testing in Compression. BSI Group, London.

[2] International Organization for Standardization (2009) ISO 6892-1, Metallic Materials-Tensile Testing-Part 1: Method of Test at Room Temperature. International Organization for Standardization, Geneva.

[3] European Committee for Standardization (2002) Eurocode 1: Actions on Structures-Part 1-1: Densities, Self-Weight, Imposed Loads for Buildings. European Committee for Standardization, Brussels.

[4] European Committee for Standardization (2003) Eurocode 1: Actions on Structures-Part 2: Traffic Loads on Bridges, European Standard EN 1991-2. European Committee for Standardization, Brussels, Belgium.

[5] European Committee for Standardization (2005) Eurocode 8: Design of Structures for Earthquake Resistance-Part 2: Bridges, European Standard EN 1998-2. European Committee for Standardization, Brussels.

[6] Bentley Systems Incorporated (2002) RM Bridge V8i 08.10.03.02 Design Software. Bentley Systems Incorporated, California.

[7] European Committee for Standardization (2005) Eurocode 2: Design of Concrete Structures. European Committee for Standardization, Brussels.

[8] Highways Agency (2001) BD 44/95-Design Manual for Roads and Bridges Volume 3, Section 4, Part 14-The Assessment of Concrete Highway Bridges and Structures. Highways Agency, Guildford.

[9] Highways Agency (2001) BD 21/01-Design Manual for Roads and Bridges Volume 3, Section 4, Part 3-The Assessment of Highway Bridges And Structures.

[10] European Committee for Standardization (2005) Eurocode 6: Design of Masonry Structures-Part 1-General Rules for Reinforced and Unreinforced Masonry Structures, European Standard EN 1996-1. European Committee for Standardization, Brussels. 
Submit or recommend next manuscript to SCIRP and we will provide best service for you:

Accepting pre-submission inquiries through Email, Facebook, LinkedIn, Twitter, etc. A wide selection of journals (inclusive of 9 subjects, more than 200 journals)

Providing 24-hour high-quality service

User-friendly online submission system

Fair and swift peer-review system

Efficient typesetting and proofreading procedure

Display of the result of downloads and visits, as well as the number of cited articles Maximum dissemination of your research work

Submit your manuscript at: http://papersubmission.scirp.org/

Or contact ojce@scirp.org 